\title{
ПРИРОДНО-КЛИМАТИЧЕСКИЕ ФАКТОРЫ РАЗВИТИЯ ЗЕМЛЕДЕЛИЯ ЮЖНОГО КАЗАХСТАНА В СРЕДНИЕ ВЕКА
}

\author{
(C) 2020 г. Саида Араповна Нигматова ${ }^{1,2}$ \\ ${ }^{1}$ д.г.-м.н., руководитель лаборатории мезозоя и кайнозоя, \\ Институт геологических наук им. К. И. Сатпаева; \\ ${ }^{2}$ ведущий научный сотрудник, Институт археологии им. А.Х. Маргулана, \\ Алматы, Казахстан. E-mail: nigmatova@mail.ru
}

\begin{abstract}
Аннотация: В бассейне реки Сырдарья в Южном Казахстана известно большое количество археологических памятников, свидетельствующих о развитии земледелия на данной территории в историческом прошлом. Изучение геоморфологии, геологического строения этой обширной территории и реконструкция палеоклимата на основании палинологического анализа голоценовых отложений многочисленных торткулей, рабатов и городищ Южного Казахстана позволили установить существование благоприятного климата для развития сельского хозяйства, садоводства. Палинологические исследования дали возможность выделить относительно более влажные и прохладные периоды, в течение которых происходило остепнение пустынной растительности, расширение пойменных лесов, расширение пойм рек, обводнение родников и колодцев. Выделены и охарактеризованы различные в геоморфологическом отношении участки, расположенные вдоль реки Сырдарья. Показаны этапы изменения особенностей хозяйственного освоения этой территории.
\end{abstract}

Ключевые слова: археология, голоцен, окружающая среда, геоморфология, палинология, земледелие

\section{ОНТУСТІК ҚАЗАКСТАНДА ОРТАҒАСЫРЛАРДАҒЫ ЕГІН ШАРУАШЫЛЫҒЫ ДАМУЫНЫН ТАБИҒИ-КЛИМАТТЫК ФАКТОРЫ}

\section{Саида Араповна Нигматова ${ }^{1,2}$}

${ }^{1}$ г.-м.ғ.Д., мезозой мен кайнозой зерттханасының жетекшісі,

Қ. И. Сәтпаев атындағы Геология ғылымдардың институты;

${ }^{2}$ ЖҒ, Ә.Х. Марғұлан атындағы Археология институты, Алматы қ., Қазақстан. E-mail: nigmatova@mail.ru

Аннотация. Оңтүстік Қазақстандағы Сырдария өзенінің алабында тарихи өткен кезеңдерде егін шаруашылығының дамығандығына куәгер боларлықтай көптеген археологиялық ескерткіштер баршылық. Оңтүстік Қазақстанның көптеген төрткүл, рабаттары қалаларының голоцендік түзілімдерінің тозаңдық сараптамасының негізінде геоморфологиялық, осынау ауқымды аумақтағы геологиялық құрылымды және палеоклиматты қалпына келтіруді зерттеу барысында ауыл шаруашылығы мен бақ өсіру үшін қолайлы климат болғандығы анықталды. Тозаңдық зерттеу анағұрлым ылғалды және салқын кезеңдерін, солардың ағымында шөл өсімдіктерінің далалануы, жайылма ормандардың кеңеюі, өзен жайылымдарының кеңеюі, бұлақтар мен құдықтардың 
суландырылуының жүруін анықтауға мүмкіндік берді. Сырдария өзенінің бойында әртүрлі геоморфологиялық қатынаста орналасқан телімдер бөлініп көрсетілді және оларға сипаттама берілген. Осы аумақтағы шаруашылықты игеру ерекшеліктерінің өзгеру кезеңдері көрсетілген.

Түйін сөздер: археология, голоцен, қоршаған орта, геоморфология, палинология, егін шаруашылығы

\title{
NATURAL AND CLIMATIC FACTORS OF SOUTH KAZAKHSTAN AGRICULTURE DEVELOPMENT IN THE MIDDLE AGES
}

\author{
Saida A. Nigmatova ${ }^{1,2}$ \\ ${ }^{1}$ Doctor of Geological and Mineralogical Sciences, Head of the Laboratory \\ of Mesozoic and Cenozoic Geology, Satbayev Institute of Geological Sciences; \\ ${ }^{2}$ leading researcher, A. Kh. Margulan Archeology Institute, \\ Almaty, Kazakhstan.E-mail: nigmatova@mail.ru
}

\begin{abstract}
In the Syr Darya river basin in Southern Kazakhstan, a large number of archaeological sites are known, indicating the development of agriculture in this territory in the historical past. The study of geomorphology, the geological structure of this vast territory and the reconstruction of the paleoclimate on the basis of a palynological analysis of Holocene deposits of numerous tortkuls, rabats and settlements of South Kazakhstan made it possible to establish the existence of a favorable climate for the development of agriculture and horticulture. Palynological studies made it possible to distinguish relatively wetter and cooler periods during which desert vegetation steppificated, floodplain forests expanded, river floodplains expanded, springs and wells were watered. Geomorphologically different areas along the Syr Darya River have been identified and characterized. The stages of change of peculiarities of economic development of this territory are shown.
\end{abstract} agriculture

Keywords: archaeology, Holocene, environment, geomorphology, palynology,

Введение

Современный уровень археологических исследований предполагает использование целого комплекса междисциплинарных методов, позволяющих корректно и всесторонне восстанавливать естественную последовательность исторических событий. Одним из наиболее распространённых и результативных методов является палинологический анализ, который основан на изучении спор и пыльцы растений, сохранившихся в осадочных отложениях. Кроме того, палинологический метод опирается на изучении современной растительности и геолого-геоморфологического строения территории.
При проведении палинологических исследований может быть решен широкий круг вопросов: выяснение состава палеорастительности района исследования, изменения растительного покрова до возникновения памятника, во время и после прекращения его функционирования и изменения климата, палеогеографической обстановки во время существования археологического объекта, состав культурной растительности. Изучение культурного слоя, кроме того, позволяет в ряде случаев выявить появление в данном регионе культурных растений и в редких случаях последовательность смены выращиваемых культурных растений. 
Вопрос об аграрном развитии Южного Казахстана в Средневековье на первый взгляд кажется достаточно проблематичным, так как современный аридный климат (сухой и жаркий) определяет пустынную растительность с обычным для этой территории набором ксерофитной полукустарничковой и кустарниковой растительности. Однако свидетельством существования благоприятных условий для проживания людей и развития земледелия здесь в прошлом является большая концентрация археологических памятников, таких как городища, рабаты, кяризы.

В 2002-2005 годах в связи с реализацией грантового проекта INTAS Project 0-06999 «Geo-archaeological investigations of land use and irrigation works in Kazakhstan in present and in historical times» («Геоархеологическое изучение использования ландшафтов для ирригационных систем в историческое время в Казахстане») под руководством Б. Ж. Аубекерова и Р. Сала было начато планомерное и комплексное палинологическое изучение средневековых памятников Южного Казахстана, которое продолжается до сих пор. Был накоплен большой фактический материал как по данным изучения позднеголоценовых отложений (охватывающих возрастной интервал от 5000 лет назад до настоящего времени), так и по палинологическому изучению археологических памятников - курганов, городищ, рабатов, тобе.

На палинологический анализ с целью установления климата региона в средние века и вероятности произрастания садово-парковых культур на территории Южного Казахстана было отобрано более 300 образцов из различных шурфов на территории древ- них городов и оазисов Отрар, Сауран, Туркестан и прилегающих районов.

Геолого-геоморфологические особенности района археологических памятников Южного Казахстана

Наиболее развитая в сельскохозяйственном отношении территория Южного Казахстана расположена между горами Каратау и рекой Сырдарья на четвертичных аккумулятивных наклонных равнинах у подножия гор Каратау. Западнее располагаются плодородные земли древних и современных дельт реки Сырдарья, которые в течение длительного времени служили местом обитания людей разных эпох и культур - от эпохи неолита до наших дней.

Территорию Южного Казахстана условно можно разделить на участки (рис. 1), отличающиеся друг от друга геоморфологическими особенностями.

Участок 1 располагается между горами Каратау и рекой Сырдарья. Особенностью этого района является тесная взаимосвязь археологических объектов разных эпох с горами Каратау и долиной реки Сырдарья.

Наиболее важной частью этой территории являются горы Каратау с многочисленными родниками, урочищами, пещерами. Здесь была возможность найти пропитание и кров.

Горы Каратау с выходами скальных пород с глубокими ущельями сложены в основном палеозойскими (541-252 млн. лет назад) морскими отложениями. В своем современном виде горы возникли в результате неотектонических движений, которые также вовлекли в поднятие горизонтально лежащие морские и континентальные мезозой-кайнозойские отложения с амплитудой поднятия до нескольких сотен метров (500-800 м), 


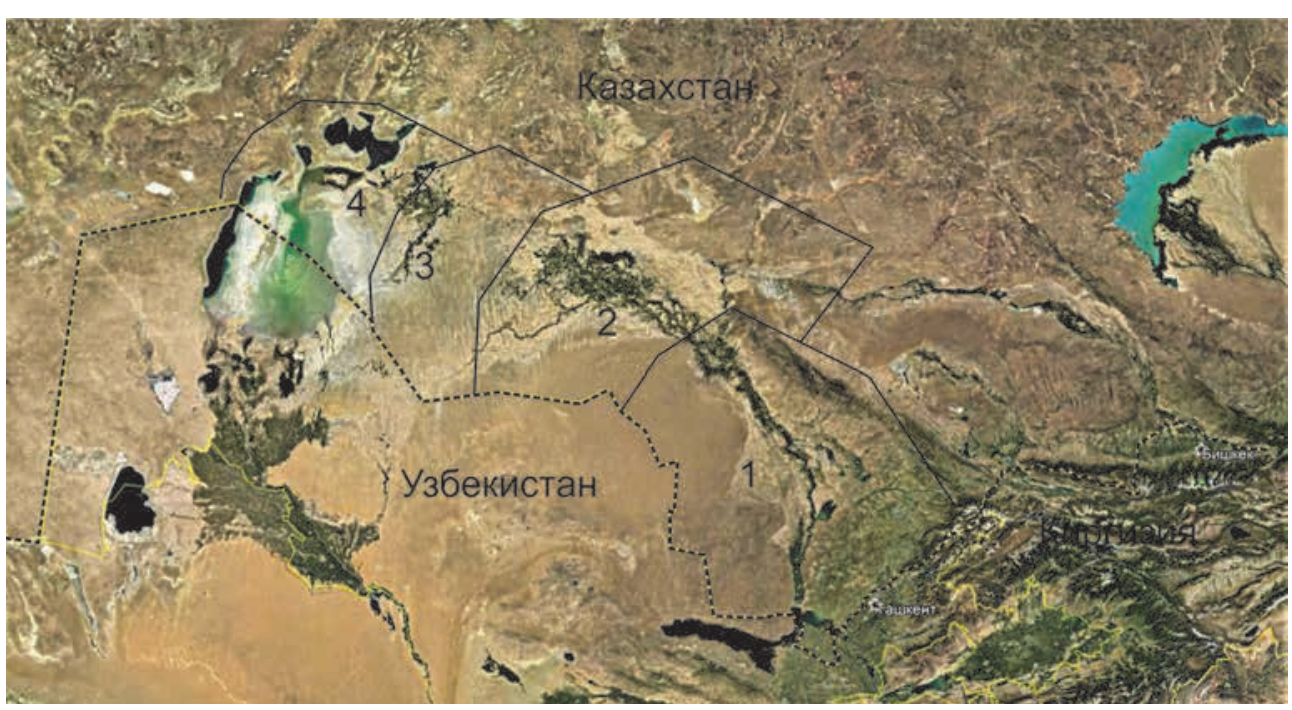

Рис. 1. Карта-схема Южного Казахстана и расположения участков (1-4) с сельскохозяйственным потенциалом

Fig. 1. Map-diagram of South Kazakhstan and location of areas (1-4) with agricultural potential

что предопределило формирование артезианского бассейна, воды из которого посредством кяризов доставлялись к полям. В геологическом строении территории принимают участие четвертичные аллювиальные и пролювиальные отложения вдоль гор Каратау (поздний плейстоцен) и аллювиальные отложения речной системы, состоящей из долин рек Сырдарья и Арысь, имеющих две надпойменные террасы (средний-поздний плейстоцен) и пойму (голоцен).

Склоны прорезаны многочисленными долинами рек, которые устремляют свои воды в сторону реки Сырдарья, однако только в весенний период немногие достигают ее. При выходе из гор долины рек формируют неширокую полосу пролювиальных конусов выноса, сложенных крупными обломками пород, сносимых с гор Каратау и обычно перекрытых лёссом или лессовидным суглинком. Эти участки начали использоваться уже в неолите, на ранних стадиях формирования человеческих культур.

С развитием орудий труда появилась возможность осваивать обширные аллювиальные равнины, расположенные между Каратау и рекой Сырдарья. Аллювиальные равнины сложены гравийниками, песками и супесями различной мощности. Высота равнин над уровнем моря 200-300 м. Аккумулятивные равнины прорезаны долинами небольших рек, стекающими с гор Каратау.

В качестве опорного разреза для северных предгорий Каратау приводим материалы исследований памятника эпохи бронзового века Арпаузен (рис. 2). Участок Арпаузен расположен на северо-восточном склоне хр. Каратау. Склоны обычно выпуклые или прямые, здесь часто обнажаются скальные породы. Еще северо-восточнее наблюдается тектонически поднятый блок, сложенный девонскими красноцветными песчаниками, 


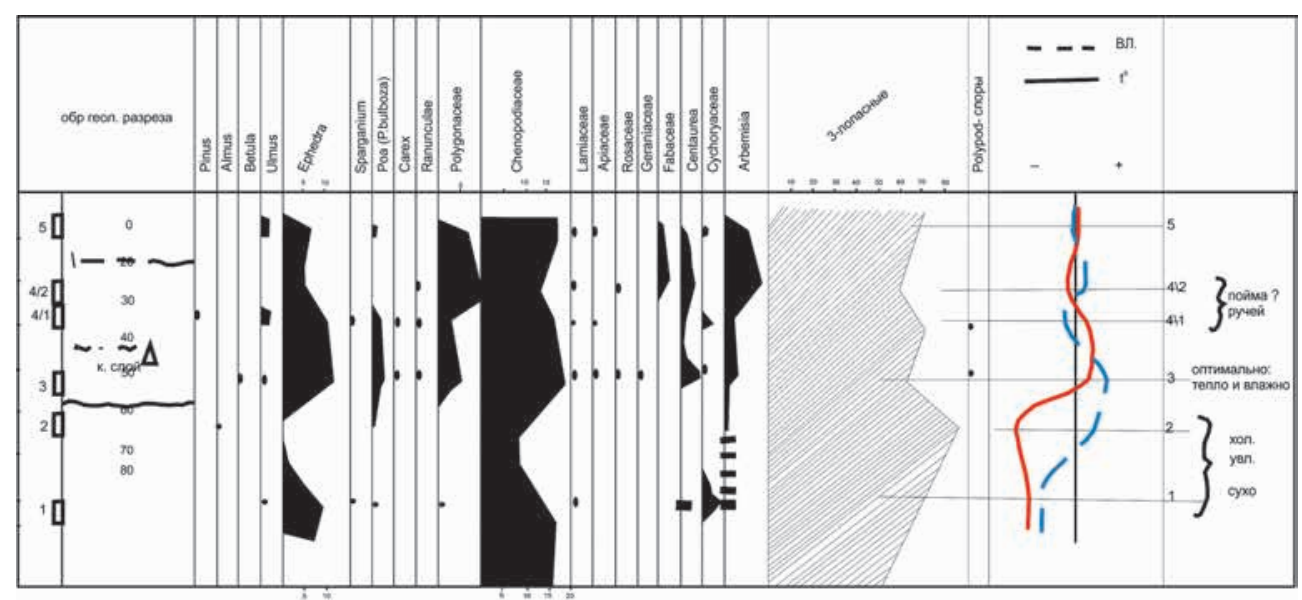

AMATPAMMA NO APIRY3EHb 2005:

Рис. 2. Палинологическая диаграмма голоценовых отложений гор Kapamay, ур. Арпаузен

Fig. 2. Palynological diagram of Holocene deposits of the Karatau Mountains, Arpauzen stow

прорезанными долинами с крутыми склонами, обращенными в сторону долины, на которых встречены петроглифы.

Палинологические материалы показывают существование в раннем голоцене холодных пустынь. Здесь выделяются два этапа - относительно холодный и влажный в начале и более теплый и сухой в верхней части разреза.

Река Сырдарья протягивается более чем на 3000 км и образует дельту при впадении в Аральское море. История развития долины реки Сырдарьи определялась блужданием русла реки по аллювиальной равнине с тенденцией смещения русла на правобережье. Полноводность реки зависит от климатических колебаний, с которыми связано количество льда в горных ледниках, и от количества выпадающих дождей и снега в течение года. Современное положение долины было сформировано в течение позднего неоплейстоцена и голоцена.
Ширина долины изменялась в пределах от 30 и 60 км (этапам более влажного климата соответствовала большая ширина долины и более крупные меандры русла реки). Старые русла имеют плесы, которые подпитываются грунтовыми водами и весенними паводками. За прошедшие 4000 лет наблюдается тенденция к прогрессирующей аридизации климата и в этой связи происходит уменьшение ледников в горах Тянь-Шаня и, соответственно, изменение уровня воды в реке.

Палинологическое изучение голоценовых отложений реки Сырдарья позволило провести реконструкцию климата за последние 2500 лет (рис. 3). Верхняя часть разреза характеризует климат малого ледникового периода, выпавшего на позднее средневековье, и некоторое потепление в раннем средневековье. Средняя часть разреза сопоставляется с похолоданием раннего железного века, а нижняя часть характеризуется более аридным 
Нигматова С.A. Природно-климатические факторы развития земледелия Южного Казахстана...

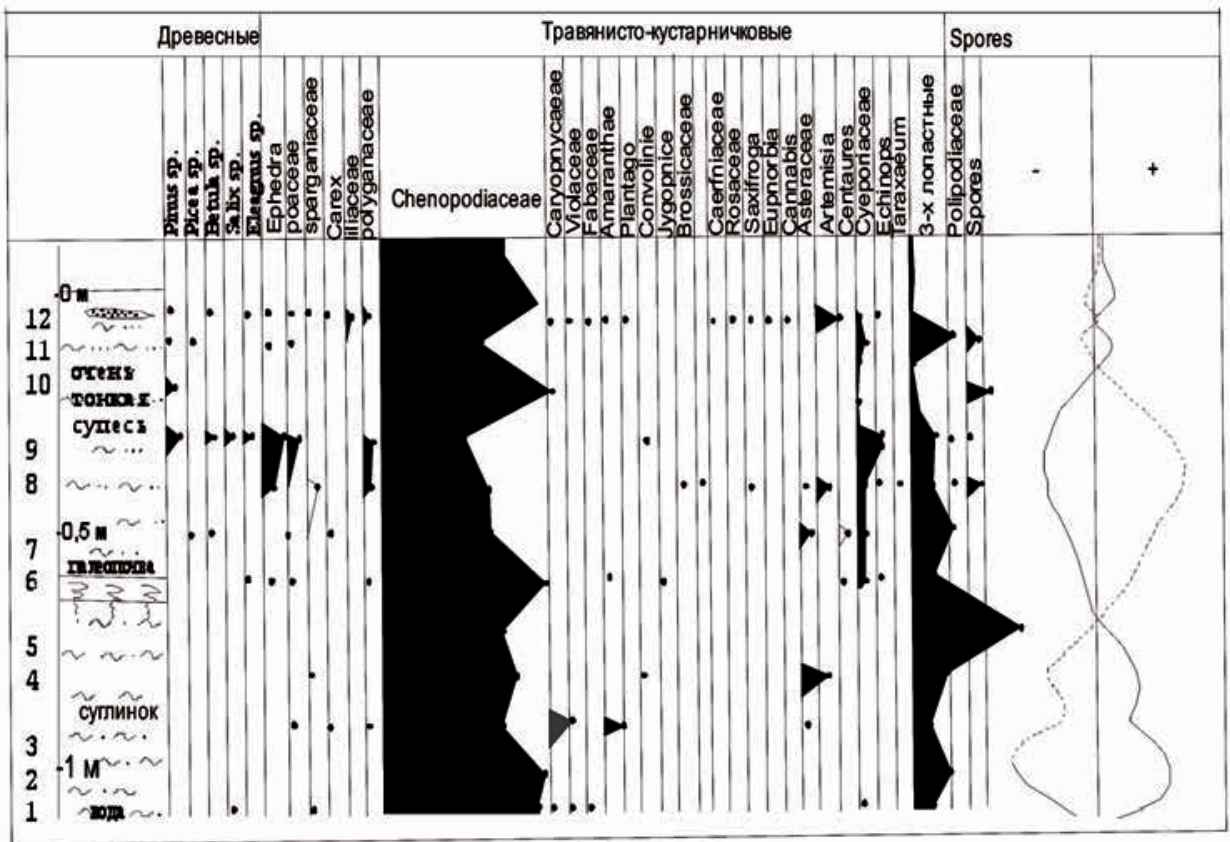

Рис. 3. Палинологическая диаграмма голоценовых отложений p. Сырдарья (по: [Нигматова, 2010])

Fig. 3. Palynological diagram of Holocene deposits of the Syr Darya River (by: [Nigmatova, 2010])

и жарким климатом конца бронзового века - начале раннего железа.

В нижнем течении долина реки Сырдарьи проходит через восточные части пустыни Кызылкум и характеризуется частыми наводнениями. Перед этой областью река Арысь представляет последний крупный приток, вокруг которого расположен Отрарский оазис. На этом участке река Сырдарья поворачивает на запад, контролируемая неотектоническими структурами, расположенными параллельно горам Каратау.

В условиях более влажного климата район Майлытогай и Маякум, а также некоторые участки старой дельты в пустыне Кызылкум имели хорошие возможности для развития поливного земледелия с простыми схемами ирригации. Руины ранних средневе- ковых городов и поселений найдены во всех этих областях [Боровский, Погребинский, 1958, с. 417].

В Присырдарьинском районе в голоцене накапливались отложения сырдарьинской свиты, сложенные аллювиальными и озерно-аллювиальными отложениями мощностью до 10-30 м (песок, супеси, суглинки, глины). Изучение голоценовых отложений поймы реки Сырдарья по соотношению основных групп растений позволило выделить три этапа изменения растительности:

1 этап характеризуется практически полным отсутствием пыльцы древесных. Только на глубине 1,1 м зафиксированы единичные пыльцевые зерна ивы. Высокое содержание пыльцы маревых (от 66 до 87\%) при 
достаточно бедном видовом составе пыльцы других растений свидетельствует о развитии полупустынной и пустынной растительности в значительном удалении от поймы.

Некоторая оптимизация климата в сторону увеличения влажности и уменьшения температуры намечается на глубине 1,1-0,8 м. В целом, климат этого этапа значительно более сухой и теплый (аридный) чем современный.

2 этап характеризуется появлением в спектрах единичной пыльцы древесных растений - березы, ивы, лоха, ели, сосны. Среди травянистых появляется значительное разнотравье. Кроме того, в спектрах появляется пыльца эфедры (характерной для открытых пространств, пионерной), заметно уменьшается роль маревых - от 80 до $43 \%$.

Значительно меняется видовой состав - появляется пыльца более мезофильных растений - злаков, ежеголовки, осоки, гречишных, губоцветных, сложноцветных (Centaurea), цикориевых, появляются споры папоротников и мхов. Все это свидетельствует об оптимизации климата увеличении влажности и уменьшении температуры. Возможно и о приближении поймы.

3 этап характеризует резкая аридизация климата и его постепенное восстановление до современного уровня.

Завершают разрез спектры, которые характеризует современный этап развития растительности и климата.

Аналогичные данные получены из отложений поймы реки Арысь, где выделено шесть этапов изменения растительности и климата.

Палинологическое изучение отложений средневековых оазисов

Наиболее интересные результаты были получены при изучении памятника средневекового паркового искусства - Миртобе, исследованного Е. А. Смагуловым [Смагулов, 2011]. Образцы на палинологический анализ были отобраны автором в 2015 г. В планиграфии Миртобе хорошо выделяются четкие линии стен и валов, окружавших отдельные элементы сада, ровные каналы. Вероятно, было четыре зоны, представляющих четыре уголка мира, и четыре реки рая. Здесь были опробованы бассейн, хорошо различимый на аэрофотоснимках, территория «сада», рабатов. Палиноспектры «бассейна» содержат массу водорослеподобных форм, фрагментов нитчатых водорослей, пыльцу гвоздичных, астровых, губоцветных, злаков. Кроме того, установлена пыльца нимфейных. Возможно, в водоеме цвели кувшинки, а вокруг него располагались цветочные клумбы.

Установлена пыльца следующих декоративных деревьев: восточный чинар (Platanus orintalis), кипарис (Cupressus sempervirens), тополь (Populus alba), красный клен (Acer rubrum), можжевельник (Juniperus comminis или Puramidalis) и стройный кедр (Jucense), ясень (Fraxihus excelsior), дуб каменный (Quercus ilex), вяз (specis Ulmus), а также хвойных пород - зонтичная сосна (Pinus pinca).

При создании сада использовались и декоративные кустарники в виде изгороди, усиливая, совместно с водными каналами, геометрию планировки сада, его симметрию. Вероятно, арки были увиты виноградниками. Популярны вьюнки (Convolulus cneorim) с желтыми, в центре белыми цветами, которые появляются в течение всего лета. Пыльца перечисленных видов выделена из изученных спектров из шурфов, пройденных на территории Миртобе. 
Нигматова С.A. Природно-климатические факторы развития земледелия Южного Казахстана...

Кроме того, участие в палиноспектрах пыльцы хлопчатника, винограда указывает на то, что помимо культурно-эстетической, существовала и агропромышленная зона, где выращивались эти растения.

Малое количество пыльцы культурных растений (не превышающее $10 \%$ ) в «продуктивных» палиноспектрах объясняется кратковременностью существования садов на территории Миртобе, не превышающее 200 лет. За это время был накоплен незначительный по мощности слой с пыльцой культурных растений, который изрядно «разбавлен» фоновой пыльцой пустынной ксерофитной растительности.

Интересные данные получены при изучении Отрарского оазиса. Культурный слой здесь характеризуется наличием пыльцы сорных растений, сопровождающих посевы различных злаков.

Оазис Отрар расположен в зоне слияния рек Сырдарья, Арысь и Богунь, на севере расположена горная цепь Большого Каратау, а на юге и западе простирается пустыня Кызылкум. Особенностью геоморфологического строения является формирование широких пойм с характерным микрорельефом и широкими меандрами. При слиянии с рекой Арысь Сырдарья образует большую дельту, которая составляет главную часть оазиса Отрар.

В геологическом строении региона принимают участие четвертичные пролювиальные отложения речной системы рек Сырдарья, Арысь и Богунь, имеющих две надпойменные террасы (средний-поздний плейстоцен) и пойму (голоцен), а также дельты рек Арысь и Богунь (голоцен).

Палинологическое изучение было осуществлено по материалам
10 шурфов. Они показали, что климат в средневековье характеризовался значительными изменениями, это нашло свое отражение в палинологических спектрах. Наиболеепредставительным является разрез шурфа 181 (рис. 4), расположенного около самого Отрарского оазиса.

1 этап (основание разреза (рис. 4)) характеризуется присутствием в спорово-пыльцевых спектрах (СПС) пыльцы растений, не произрастающих в настоящее время в этом регионе и связанных со значительно более влажным и умеренным климатом - это пыльца липы, берез, ольхи (Tilia sp., Betula sp., Alnus sp.). Можно предположить, что пробы 1 и 2 вскрывают более древние отложения, чем голоценовые.

2 этап - характеризуется полным отсутствием растительных остатков.

3 этап - большое число пыльцевых зерен полыней (Artemisia sp.), маревых (Chenopodiaceae), эфемерная растительность представлена пыльцой маков Papaver, злаков Poaceae, василька Centaurea, эремуруса Eremurus, встречены единичные пыльцевые зерна конопли - Cannabis. Наряду с пыльцой в спектре богато представлены почвенные грибы, остатки растительных тканей и др. органика. Все это указывает на существование теплого, с достаточно большой влажностью климата, продолжительным временем цветения и развития эфемеров, что характерно для пойменных лугов.

4 этап - резко отличается от предыдущего большим числом пыльцы Sparganium(Ежеголовка) - водного, прибрежно-водного растения из семейства злаков, распространенного в настоящее время по всем водоемам 


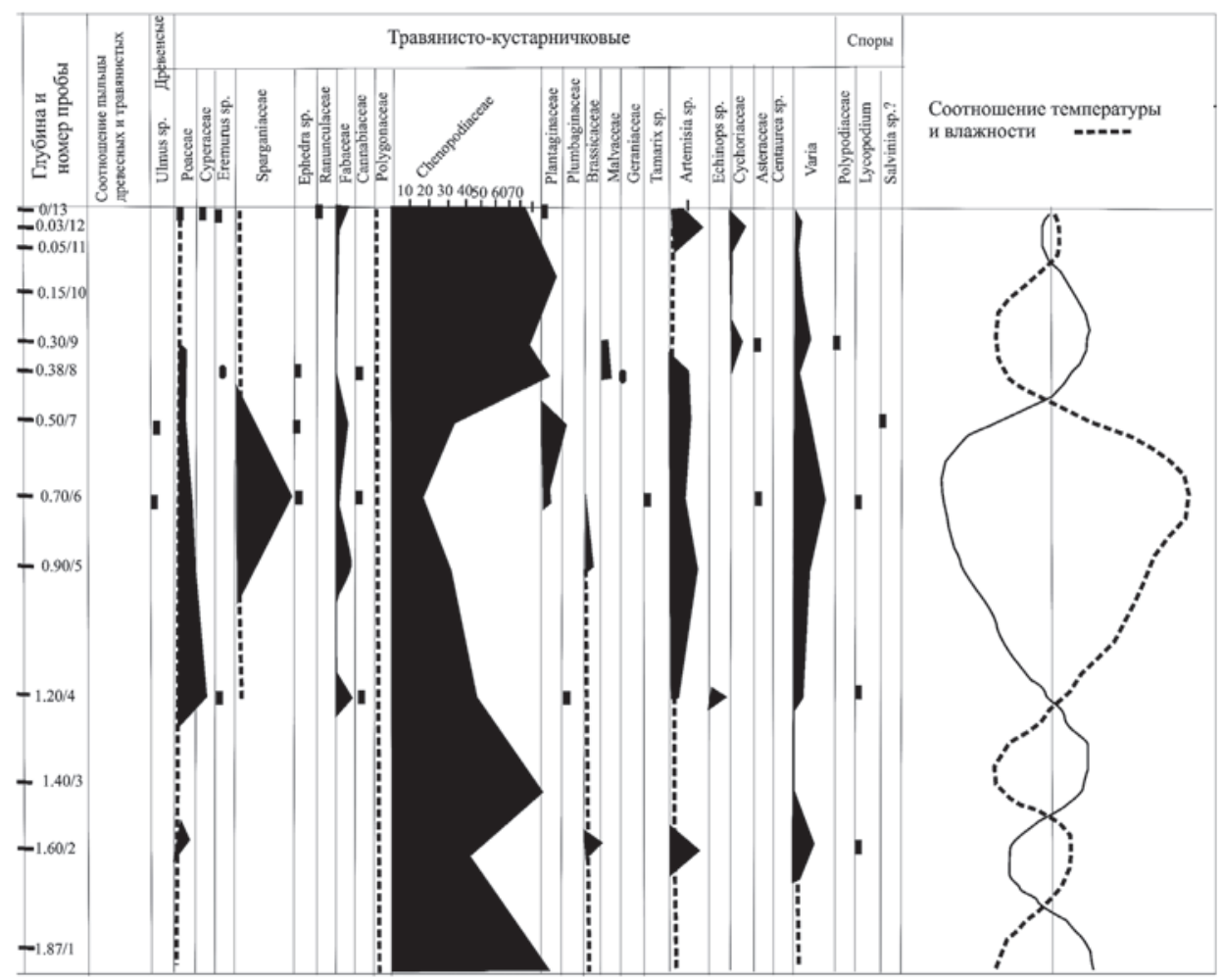

Рис. 4. Палинологическая диаграмма голоценовых отложений Отрара, шурф 181 (верхняя часть разреза)

Fig. 4. Palynological diagram of Holocene deposits of Otrar, pit 181 (upper part of the section)

Азии и часто являющегося сорняком рисовых полей(?). Кроме этого, на обводненнность указывает и большое число пыльцы разнотравья, водорослеподобные остатки. Это ископаемый почвенный слой, развитый на пойменных отложениях, мог быть использован как наиболее пригодный для посевов злаков.

5 этап - характеризуется очень малым числом пыльцы ежеголовки (число ее пыльцы резко уменьшается вверх по разрезу), увеличением участия в СПС пыльцы маревых, появление ПЗ эфедры и сложноцветных. По-видимому, этот этап был более засушливым (менее влажным), чем предыдущий. Этот этап интересен появлением пыльцы хлопчатника (в настоящее время в Казахстане нет диких форм хлопчатника, встречаются только окультуренные виды в Западном Тянь-Шане). В геологическом разрезе этот слой оценивается как новый этап накопления пойменных отложений и благоприятное время для хлопководства.

$$
6 \text { этап - отличается малым }
$$
числом встреченных пыльцевых зерен, в основном маревых, много обгорелых обломков древесины. Единичны злаки, разнотравье, возможно засоление почв. 
Нигматова С.A. Природно-климатические факторы развития земледелия Южного Казахстана...

7 этап - иллюстрируют современную растительность региона. Преобладают маревые, полыни, встречены пыльца злаков, сложноцветных (васильков, кузиний) разнотравья.

Для этих районов были характерны экстенсивные способы ведения сельского хозяйства. Быстрое засоление почвы приводило к частой смене возделываемых участков, только после значительного перерыва эти поля использовались повторно. Часто при этом менялась возделываемая культура.

Вероятно, при достаточном увлажнении, на этом поле высевался рис (на что указывает большое количество пыльцы сорного растения ежеголовки, характерной для рисовых чеков, и пыльца Eleagnus sp. - лоха (джида), произраставшего вдоль каналов и полей). Выше по разрезу состав спорово-пыльцевых спектров существенно меняется и указывает на значительный перерыв, после которого на этом поле стали высевать другие агрокультуры, возможно, хлопчатник. На это указывает установленная немногочисленная пыльца хлопчатника совместно c пыльцой сорных растений, сопутствующих культурным посадкам, этот вывод о посевах риса и хлопчатника подтверждается составом палиноспектров, изученным современных спектров рисовых чеков и хлопковых полей.

Пески пустыни Кызылкум охватывают огромную территорию, включающую междуречье Сырдарьи и Амударьи и побережье Аральского моря. Песчаные массивы сформированы эоловыми процессами и состоят из системы гряд субмеридионального направления и бугристых песков, имеющих в среднем высоту 5-15 м.
На всей территории Кызылкум нет поверхностных водотоков, но имеются богатые запасы пресных напорных подземных вод. Сыпучие пески имеют большую влажность по сравнению с уплотненными, хотя последние отличаются большим плодородием. Конденсируя влагу из воздуха, сохраняя воду, приносимую дождями и снегом, пустыня сохраняет этот бесценный дар в своих глубинах. Под Кызылкумом на глубине более 100 м расположены озера с пресной и полупресной водой. Часть этой воды этим озерам доставляют стекающие с гор реки.

На закрепленных песках, помимо различных травянистых и кустарничковых растений, произрастают кустарники и деревья. На песчаных почвах, укрепляя подвижность барханов, произрастают черный и белый саксаул, песчаная акация, черкез, эфедра, джузгун и многие другие виды.

Участок 2 - междуречье рек Шу и Сарысу. Район характеризуется развитием обширных аллювиальных равнин при слиянии правых притоков реки Сырдарья, Сарысу и Шу. Эти крупные притоки и другие, более мелкие, в течение голоцена имели неоднократный сток в долину реки Сырдарья, а также неоднократно этот сток прекращался в связи с изменением климата. Мелкий наилок, выносимый реками Сырдарья и Шу, приводил к изменению режима стока, в результате чего наблюдались периодические смещения сельскохозяйственных угодий, то ближе к Сырдарье (аридная фаза), то в сторону от долины реки Сырдарья (плювиальная фаза).

Этот район был благоприятен для проживания людей, они находили в этих районах благоприятные условия для зимовок и для развития 
земледелия. Здесь установлены места зимовок больших стад сайги, диких кабанов, а в весенне-осеннее время этот район является местом для перелёта птиц из тёплых краёв на север и обратно.

Участок 3 включает плодородные земли древних и современных дельт реки Сырдарья, которые служили местом обитания в течение длительного времени людей разных эпох и культур, от эпохи неолита до наших дней.

Этот район, для которого были характерны многочисленные протоки, небольшие озёра и обширные заливные луга, был благоприятным для развития городской цивилизации средневековья, земледелия, охоты, рыболовства и местом зимовок кочевников. В этих районах сохранились многочисленные городища, ирригационные системы, которые, однако, в отличие от вышеописанных трёх участков, располагались на левобережье. На правобережье количество ирригационных систем и поселений было меньше в связи с непостоянством ландшафтных условий и непостоянным режимом стока рек Сарысу и Шу в долину реки Сырдарья. Эти районы, сложенные тонким песком и лёссовидным суглинкам, достаточно быстро опустынивались, а аллювиальные отложения перевивались и формировали эоловый рельеф.

Участок 4 - Приаральский район, где современная дельта реки Сырдарья и побережье Аральского моря создавали специфические условия для формирования культур разного типа.

Прибрежная зона Аральского моря и современная дельта реки Сырдарьи являлись благоприятным местом для жизни. Дельты рек Амударьи и Сырдарьи были своеобразными зелеными оазисами среди пустыни. Обширные тополёвые рощи, заросли тугаёв, широкие луга, были благоприятны для обитания многочисленных птиц и животных, таких как тигр, дикие козлы и сохранившиеся до настоящего времени шакалы, волки, лисы и другие мелкие млекопитающие. Природные богатства дельт составляли густые заросли тростника, тугайные леса, озера, богатые рыбой, водоплавающей птицей и ондатрой, сенокосные угодья, пастбища и орошаемые земли.

Начало активного орошаемого земледелия в регионе прослеживается с VI-VII вв. до н.э. и совпадает с наивысшим расцветом древнейшей цивилизации, где орошение являлось основным решающим фактором исторического и социальноэкономического развития. С развитием земледелия на естественные периоды колебания моря начинают заметно влиять и антропогенный фактор, изменяющий стоки рек Сырдарьи и Амударьи.

Археологический памятник Кердары в Приаралье является уникальным среди средневековых памятников западной части аридной зоны. После высыхания Аральского моря на его обсохшем дне, где глубина воды ранее достигала не менее 8 м, было обнаружено средневековое городище XIV в. с хорошо развитой инфраструктурой (поселение с хорошо различимыми постройками, многочисленными артефактами в виде керамики, ирригационными системами, угодьями, некрополем, а также мавзолеем, расположенным в 3 км западнее самого поселения Кердары [Байпаков и др., 2007].

Эти находки свидетельствуют о том, что колебания уровня Аральского моря происходили неоднократно в течение всего времени его существования [Веселов и др., 1999.]. 
Нигматова С.A. Природно-климатические факторы развития земледелия Южного Казахстана...

Изучение разрезов шурфов, пройденных непосредственно на территории поселения, показывает, что оно расположено на мощном слое однородного, хорошо отсортированного морского песка, выше которого лежат слоистые песчаные и глинистые морские отложения.

Над ними хорошо выделяется более темный горизонт, соответствующий времени, когда поверхность не была покрыта водой и сформировались почвы, подобные современным лугово-болотным почвам (культурный слой со средневековыми артефактами). Верхняя часть разреза сложена современными морскими отложениями с большим количеством ракушек, которые перекрывают почвенный культурный слой.

Палинологический анализ отложений с глубины 1,1 м и до 0,05 м позволил выделить и изучить споровопыльцевые спектры, неравнозначные по составу и количеству пыльцы. Интерпретация полученных материалов позволила нам выделить следующие этапы в формировании изученных отложений (рис. 5):

1 этап (снизу - вверх) - характеризуется небольшим числом пыльцевых зерен - 60 шт. Доминирует пыльца травянисто-кустарничковых растений, среди них маревых (Chenopodiaceae) 42\%, на пыльцу полыней приходится 27,5\% (Artemisia), 7\% принадлежит пыльце ежеголовки (Sparganiaceae) - прибрежно-водному растению. По 5\% представлены эфедра (Ephedra), злаки (Роaceae), коноплевые (Cannabiaceae). По 2,5\% - крестоцветные (Brassicaceae) и васильки (Centaurea). Данный палиноспектр отражает развитие пустынной растительности в условиях небольшого увлажнения близ водоема. Небольшое число пыльцевых зерен может указывать на удаленность места захороне- ния пыльцы от места произрастания растений, продуцирующих ее.

2 этап. В палиноспектре, отражающем формирование отложений этого этапа, обращает внимание участие большого числа переотложенных спор и пыльцы хвойных из мезозойских отложений (до 40\%). Пыльца голоценовых растений представлена маревыми (Chenopodiaceae) - 25\%, полынями (Artemisia) - 20\% и трехлопастными формами - 15\%. Большое число переотложенной пыльцы и спор указывает на активный размыв более древних отложений в данный отрезок времени. Косвенно такой размыв может указывать на чрезвычайно увлажненные условия.

3 этап характеризуется большим числом пыльцы в спектрах (до 235 ед.). В начале этапа (0,45 м) видовой состав обеднен - маревые (Chenopodiaceae) (84\%), гречишные (Polygonaceae) и полыни (Artemisia) по 4,5\%, ежеголовка (Sparganiaceae) 3\%. Древесные - единично - пыльца cocны (Pinus) и ольхи (Alnus). Большое число пыльцы в спектре указывает на ее выпадении в осадок в месте вероятного произрастания, т.е. на данном этапе фиксируется появление осушенных территорий с пионерной растительностью.

Следующий уровень (0,35 м) значительно отличается от предыдущего увеличением видового разнообразия - среди древесных появляется, кроме сосны, пыльца березы, в группе травянисто-кустарничковых растений резко увеличивается значение ежеголовки (Sparganiaceae) (до 30\%), на долю маревых (Chenopodiaceae) приходится 39\%, злакам и полыням (Artemisia) принадлежит по 6,3\%, гречишным (Polygonaceae) 4,3\%, в небольшом количестве встречена пыльца крапивных (Urticaceae), бобовых (Fabaceae), свинчатковых 


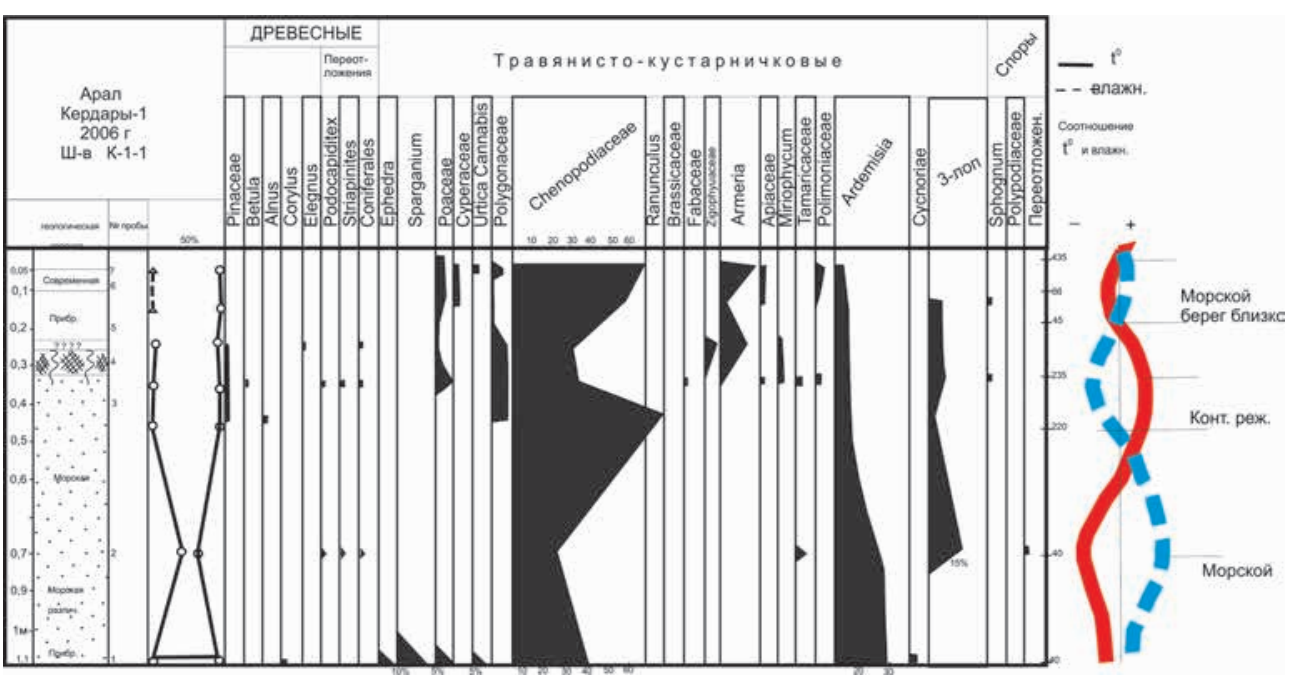

Рис. 5. Палинологическая диаграмма голоиеновых отложений Аральского моря, археологический объект Кердарь

Fig. 5. Palynological diagram of Holocene deposits of the Aral Sea, archaeological site of Kerdary

(Plumbaginaceae), парнолистниковых (Zygophyllaceae), зонтичных (Apiaceае), тамарисковых (Tamaricaeae) Вероятно, в это время формировался почвенный слой в условиях переувлажнения, на что указывает большое количество пыльцы прибрежно-водного растения ежеголовки (Sparganiaceae). Кроме того, вероятна возможность использования данной территории в целях выращивания сельхозяйственных культур, например, риса, так как ежеголовка (Sparganiaceae) является наиболее частым сорняком рисовых чеков, сама же пыльца риса устанавливается в спектрах крайне редко.

Таким образом, 3 этап отражает развитие почвенного слоя в условиях теплого и относительно сухого климата.

4 этап. Для данного этапа характерно абсолютное отсутствие пыльцы древесных пород. Среди травянистых доминируют маревые (60\%), пыльца ежеголовки (Sparganiaceae) представлена 9\%, полыней (Artemisia) - 7,5\%, в небольшом количестве установлена пыльца злаков (Рoaceae), осок (Carex), бобовых (Fabaceae), свинчатковых, цикориевых (Cychoriaceae). Вероятно, данный этап характеризует развитие пустынной растительности в прибрежных районах моря. Климатические условия были относительно прохладные и очень увлажненные.

5 этап. Спорово-пыльцевой спектр этого уровня характеризует современную пустынную растительность. Пыльца древесных отсутствует, доминирует в спектре пыльца маревых - 69\%. Злакам, маревым и полыням принадлежит от 4 до 2\%, свинчатковым - 9\%. Единично в спектре представлены осоки, коноплевые, бобовые, франкениевые, цикориевые. Климат близок к современному.

\section{Обсуждение}

Геоморфологическое изучение территории указывает на существование благоприятных условий для проживания людей на данной территории, ограниченной с одной сторо- 
ны рекой Сырдарья, с другой горами Каратау, с относительно стабильной влажностью в течение всего года, массой ущелий с достаточно умеренным климатом.

Палинологическое изучение голоценовых отложений реки Сырдарья (рис. 3) позволили провести сопоставление этих данных с эталонными спектрами из Жетысу и имеющими абсолютные даты, дали возможность скоррелировать верхнюю часть разреза с палинозонами 1, 2, характеризующими климат малого ледникового периода, выпавшего на позднее средневековье и палинозону 3 - потепление в раннем средневековье (рис. 6).

Средняя часть разреза сопоставляется нами с палинозоной 4, совпадающей с похолоданием раннего железного века на уровне 2200-1500 лет назад (ок. 2000-1800 лет назад наиболее холодный интервал).

Нижняя часть разреза, палинозона 6, характеризуется более арид- ным и жарким климатом конца бронзового века - начала раннего железа [Аубекеров и др., 2001; Нигматова, 2004; 2008].

Таким образом, в целом, не меняя принципиально общего облика, растительность и ландшафт региона претерпевали некоторые изменения в зависимости от изменения климата. В более плювиальные периоды (влажные и прохладные) происходило остепнение пустынной растительности, увеличивалось количество родников, реки и более мелкие речушки становились полноводнее, расширялись пойменные леса (тугаи). В логах появлялась кустарниковая растительность, травостой сохранялся в течение большей части лета.

Особенности хозяйственного освоения территории

На каждом историческом этапе освоение этой территории и ее четырех участков происходило поразному.

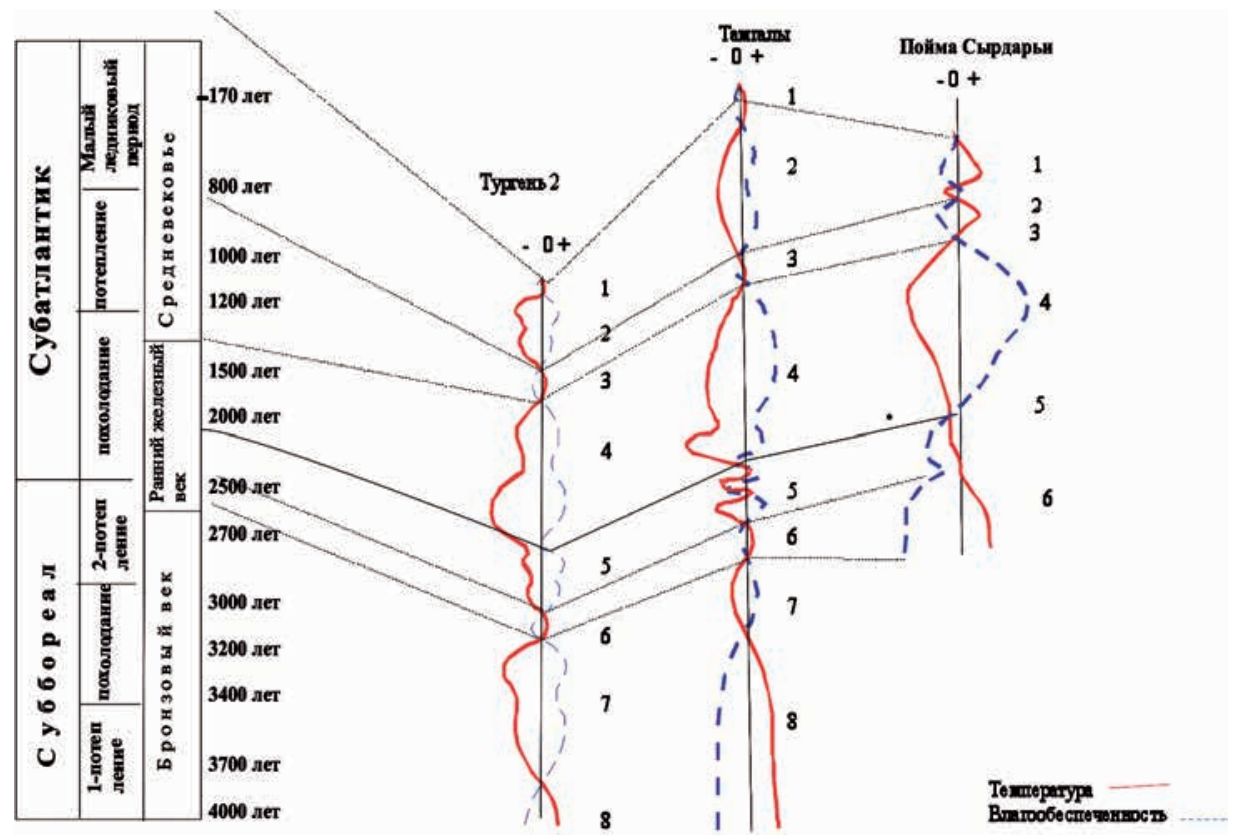

Рис. 6. Схема корреляции климатических событий Жетысу и района р. Сырдарья

Fig. 6. Correlation scheme of climatic events of Jetysu and the Syr Darya river area 
Центром заселения в каменном веке, в основном, явились горы Каратау и территория Приаралья. Здесь установлены многочисленные стоянки открытого наземного типа, а также ископаемые стратифицированные стоянки, как, например, стоянка имени Ч. Валиханова [Таймагамбетов, Кунитаке, 2019]. Это связано, прежде всего, с наличием хорошего сырья для орудий труда, многочисленных источников с пресной водой, богатым разнообразием объектов охоты, а также многочисленными ореховыми и яблоневыми рощами, служившими для питания. Хорошая сырьевая база и источники воды, а также объекты охоты были также в Приаралье и Кызылкумах, около останцов, на склонах которых сохранялись многочисленные кварцевые песчаники, из которых делались великолепные орудия.

Эпоха неолита фиксируется многочисленными стоянками вокруг Аральского моря, на берегах Сырдарьи, Кызылкумах, на территории Узбекистана и горах Каратау. Основная часть стоянок располагалась в горных долинах на останцах около выходов песчаников и иногда в пещерах.

В эпоху ранней и средней бронзы в Приаралье и на Устюрте было развито земледелие и скотоводство. Вдоль крупных долин рек Амударья и Сырдарья располагались поселения, которые уже были связаны с долинами.
Финальная часть бронзового века характеризуется резким ухудшением климата, аридными условиями, которые обусловили переход от земледельческого типа хозяйствования к преимущественно скотоводческому.

Ранний железный век характеризуется улучшением климатических условий и развитием в этом регионе земледелия и особыми формами устройства ирригационных систем. При строительстве ирригационных систем использовались поймы, которые загораживались дамбами, благодаря чему в почве длительное время сохранялась влага, которая и использовалась для выращивания зерновых культур. Такие ирригационные системы известны у подножья Каратау, где они устраивались на выходе из долин.

В эпоху средневековья развитие ирригации уже напрямую связано с долиной реки Сырдарья и ее притоками, на которых строились заградительные дамбы и по магистральным каналам вода подавалась на участки, где выращивались сельскохозяйственные культуры. Этот период хорошо известен по материалам Отрарского оазиса и многочисленным находкам поселений, усадеб или военных сооружений, которые были разбросаны в основном вдоль долины, как на правобережье вдоль гор Каратау, так и на древней дельте реки Сырдарья.

\section{ЛИТЕРАТУРА}

1. Аубекеров Б., Сала Р., Нигматова С.А., Жакупова Ш.Ж. Палеоклиматические условия аридной зоны Семиречья в эпоху бронзового и раннего железного веков. // Природные и социальные проблемы географии аридных территорий: м-лы научн.практ. конф. «Жандаевские чтения» (г. Алматы, 24-25 мая 2001 г.). Алматы: Институт геологических наук им. К.И. Сатпаева, 2001. С. 26-34.

2. Байпаков К.М., Аубекеров Б.Ж., Пачикин К., Токсеитова Г., Воякин Д., Нигматова С.А., Кузнецова Л.Л. Ландшафтные условия и природная среда времени существования поселения Кердары (Аральское море) // Проблемы экологической геомор- 
Нигматова $\boldsymbol{C . A . ~ П р и р о д н о - к л и м а т и ч е с к и е ~ ф а к т о р ы ~ р а з в и т и я ~ з е м л е д е л и я ~ Ю ж н о г о ~ К а з а х с т а н а . . . ~}$

фологии: м-лы 4 междунар. научн.-практ. конф. «Жандаевские чтения» (г. Алматы, 22-23 мая 2007 г). Алматы: Институт геологических наук им. К.И. Сатпаева, 2007. C. 64-67.

3. Боровский B.M., Погребинский М.А. Древняя дельта Сыр-Дарьи и Северные Кызыл-Кумы // Тр. Ин-та почвоведения АН КазССР. 1958. Т. І. С. 395-425.

4. Веселов В.В., Касымбеков Д.А., Махмутов Т.Т, Паничкин В.Ю., Смоляр В.А., Мирошниченко О.Л. Подземные воды Приаралья (состояние и перспективы использования) // Минерагения и перспективы развития минерально-сырьевой базы. Алматы: Гылым, 1999. Ч. 1. С. 181-196.

5. Нигматова С.А. Проблемы стратиграфии голоцена Южного Казахстана // Известия АН РК «Геология Казахстана». Сер. геол. 2004. № 6. С. 27-32.

6. Нигматова С.A. Климатостратиграфия голоцена аридной зоны Казахстана // Известия НАН РК. Сер. геол. 2008. № 5. С. 4-15.

7. Нигматова С.A. Стратиграфия, палеогеография и климаты четвертичного периода аридных регионов Центральной Азии (по палинологическим данным): дис. ... докт. геол.-мин. наук. Алматы: Институт геологических наук им. К.И. Сатпаева, 2010. $271 \mathrm{c}$.

8. Смагулов Е. Древний Сауран. Алматы: ABDI, 2011. 434 с.

9. Таймагамбетов Ж., Кунитаке С. 60 лет со дня открытия многослойной палеолитической стоянки им. Ч. Валиханова // Қазақстан археологиясы. 2019. № 3 (5). C. $62-71$.

\section{REFERENCES}

1. Aubekerov, B., Sala, R., Nigmatova, S.A., Jakupova, Sh. Zh. 2001. In: Zhandayevskie chteniya (Jandayev readings). Almaty: Satbayev Institute of Geological Sciences, 26-34 (in Russian).

2. Baipakov, K. M., Aubekerov, B. Zh., Pachikin, K., Tokseitova, G., Voyakin, D., Nigmatova, S. A., Kuznetsova, L. L. 2007. In: Zhandayevskie chteniya (Jandayev readings). Almaty: Satbayev Institute of Geological Sciences, 64-67 (in Russian).

3. Borovskiy, V. M., Pogrebinskiy, M. A. 1958. In: Trudy In-ta pochvovedeniya AN KazSSR (Proceedings Soil Science Institute of the Academy of Sciences of the Kazakh SSR), I, 395-425 (in Russian).

4. Veselov, V. V., Kasymbekov, D. A., Makhmutov, T. T, Panichkin, V. Yu., Smolyar, V. A., Miroshnichenko O.L. 1999. In: Minerageniya i perspektivy razvitiya mineralnosyrevoj bazy (Minerageny and prospects for the development of the mineral resource base). Almaty: "Gylym" Publ., ch. 1, 181-196 (in Russian).

5. Nigmatova, S. A. 2008. In: Izvestiya NAN RK (Bulletin of the National Academy of Sciences of RK). Ser. geol., 5, 4-15 (in Russian).

6. Nigmatova, S. A. 2004. In: Izvestiya AN RK (Bulletin of the Academy of Sciences RK). Kazakhstan Geology. Ser. geol., 6, 27-32 (in Russian).

7. Nigmatova, S. A. 2010. Stratigrafiya, paleogeografiya i klimaty chetvertichnogo perioda aridnyh regionov Tcentralnoj Azii (po palinologicheskim dannym): dis. ... dokt. geol.-min. nauk (Stratigraphy, paleogeography and climates of the Quaternary period in arid regions of Central Asia (according to palynological data): dis. ... doct. geol.-min. sciences.). Almaty: Satbayev Institute of Geological Sciences (in Russian). (in Russian).

8. Smagulov, E. 2011. Drevnij Sauran (The ancient Sauran). Almaty: “ABDI” Publ. (in Russian).

9. Taimagambetov Zh., Kunitake S. 2019. In: Kazakhstan Archeology, 3 (5), 62-71

\footnotetext{
Мүдделер қақтығысы туралы ақпаратты ашу. Автор мүдделер қақтығысының жоқтығын мәлімдейді. / Раскрытие информации о конфликте интересов. Автор заявляет об отсутствии конфликта интересов. / Disclosure of conflict of interest information. The authors claim no conflict of interest.

Мақала туралы ақпарат / Информация о статье / Information about the article.

Редакцияға түсті / Поступила в редакцию / Entered the editorial office: 03.06.2020.

Рецензенттер мақұлдаған / Одобрено рецензентами / Approved by reviewers: 22.06.2020.

Жариялауға қабылданды / Принята к публикации / Accepted for publication: 06.07.2020.
} 